\title{
Forward Looking Analysis Approach to Assess Copper Acetate Thermal Decomposition Reaction Mechanism
}

\author{
Itab Youssef, Sécou Sall, Thierry Dintzer, Sana Labidi* ${ }^{*}$, Corinne Petit \\ Institut de Chimie et Procédés pour l'Energie, l'Environnement et la Santé, Université de Strasbourg, UMR7515 CNRS, 25 rue \\ Becquerel, Strasbourg, France \\ Email: alkheder@unistra.fr, ssall@unistra.fr, thierry.dintzer@unistra.fr, *slabidi@unistra.fr, corinne.petit@unistra.fr
}

How to cite this paper: Youssef, I., Sall, S., Dintzer, T., Labidi, S. and Petit, C. (2019) Forward Looking Analysis Approach to Assess Copper Acetate Thermal Decomposition Reaction Mechanism. American Journal of Analytical Chemistry, 10, 153-170. https://doi.org/10.4236/ajac.2019.105014

Received: January 25, 2019

Accepted: May 7, 2019

Published: May 10, 2019

Copyright $\odot 2019$ by author(s) and Scientific Research Publishing Inc. This work is licensed under the Creative Commons Attribution International License (CC BY 4.0).

http://creativecommons.org/licenses/by/4.0/

\begin{abstract}
Thermal decomposition course of copper acetate monohydrate was monitored by combining diffuse reflectance infrared Fourier transform spectroscopy (DRIFT) coupled with $\mu$ gas chromatography-mass spectrometry ( $\mu$ GC-MS) with other analytical techniques (thermogravimetry analysis and in situ X-ray diffraction). Non-isothermal kinetic was examined in air and Ar. A complete analysis of the evolution of infrared spectra matched with crystalline phase transition data during the course of reaction allows access to significant and accurate information about molecular dynamics. While thermogravimetry gives broad conclusion about two steps reaction (dehydration and decarboxylation), in line approach (in situ X-ray and in situ DRIFT coupled to $\mu$ GC-MS) is proposed as an example of a new robust and forward-looking analysis. While decomposition mechanism of copper acetate monohydrate is still not well elucidated yet previously, the present in-line characterization results lead to accurate data making the corresponding mechanism explicit.
\end{abstract}

\section{Keywords}

In-Operando Spectroscopy and Chromatography, Thermal Decomposition Reaction Mechanism, Copper Acetate, Cross-Linked Characterization Data

\section{Introduction}

Continuous reaction and analysis is a relevant approach for sustainable chemical process [1] [2]. Ideally, techniques should provide scalable data and should be suitable for adaptation to industrial equipment (for ultimate application to process and quality control). One of the main current challenges is to design 
noninvasive techniques able to analyze data about different reaction media: powder, solid, liquid and gases. Two strategies could be proposed: continuous sampling coupled with fast analytical technique on one hand and in situ spectroscopic analysis on the other hand. Both approaches are complementary.

Metal carboxylates are useful reagents particularly for organic synthesis [3] and applied in several fields of research as solid-state, surface chemistry and catalysis [3] [4] [5] [6]. The thermal decomposition of metal carboxylates is a feasible route to synthesize metal nanoparticles suitable for catalytic purposes [7] [8] with specific properties based on carboxylates species. This reaction pathway concerning reaction media and applied conditions tailor final products yield, selectivity and chemical structure. Thermal dehydration and decomposition of metal acetate have been studied broadly under various conditions [5] [9] [10]. Copper is an interesting metal according to its properties and environmental applications. For example, $\mathrm{Cu}$ or $\mathrm{CuO}$ nanoparticles are effective to remedy a range of bacterial pathogens involved in hospital-acquired infections [9]. Some green paintings are based on copper derivatives [11] as copper acetate, silicates, $\mathrm{Cu}(\mathrm{Ac})_{2} \cdot \mathrm{H}_{2} \mathrm{O}$ has a simple process under heating, one step of dehydration followed by a step of decomposition giving rise to $\mathrm{Cu}_{\mathrm{x}} \mathrm{O}_{\mathrm{y}}$ species as presented by Mansour [5]. Thermal gravimetric analysis (TGA) was a common tool for those studies and was used by some researchers to suggest the obtained copper oxides. Other researchers proposed intermediates species as Z. Lin et al. [12] with the formation of $\mathrm{CuAc}_{2}$ peroxides. Despite intensive studies of copper carboxylates structures, no clear mechanism had been hold to illustrate thermal decomposition of these precursors. Different mechanisms for copper acetate monohydrate thermal decomposition were proposed by several authors with some disagree with each other [5] [12] [13]. Proposal of those mechanisms was based on solid material state identification only. Several techniques are conventionally added to thermogravimetry analysis (TGA) for monitoring metal carboxylates species, coupling with differential scanning calorimetry (DSC) or additional analysis of samples with X-ray diffraction (XRD), electronic microscopies or infrared (IR) [5] [12] [14]. Each technique provides specific information of gas or solid species. Moreover, developing new process based on miniaturization and coupled analysis technique made reaction study cost-effective and intensified. To obtain decomposition and reaction mechanism, single characterization technique alone could not be enough. Recently, diffuse reflectance infrared Fourier transform spectroscopy (DRIFTS) with an environmental reaction chamber was used by A. Kaftan et al. [15] to elucidate reaction mechanisms for water gas shift and methanol steam reforming. The present work deals with the development of in-situ analytical approach for thermal decomposition study of copper acetate precursor in miniaturized DRIFT chamber coupled to $\mu$ gas chromatography and mass spectrometry ( $\mu \mathrm{GC}-\mathrm{MS})$. This original coupling with new analytical approach has been developed in the lab to produce a large number of data characteristic for gas and solid species in the same time and temperature. In this article, in-situ 
XRD and TGA analysis were matched with in-situ DRIFT coupled to $\mu$ GC-MS to identify both reagents by one hand and solid and gas products by the other hand for thermal mechanism reaction. The original coupling detailed by the present work allows accessibility for accurate data about mechanism steps. This work reports in-line characterization of copper acetate monohydrate thermal decomposition as a potential example for mechanism proposal by the coupling of in-line techniques. Our article will appeal for researchers having focus on development of analytical techniques but also of solid chemistry and catalysis. It deals with an example of thermal decomposition reaction to present an optimal cross of multiple in-situ characterization results to discuss mechanism reaction with more accurate data. Mechanism understanding is crucial to control material structure, thermodynamic phase stability and synthesis process. By the present work, thermal decomposition of $\mathrm{Cu}(\mathrm{Ac})_{2} \cdot \mathrm{H}_{2} \mathrm{O}$ is used as an example to demonstrate that a simple profile of TGA correspond to complex phenomena at molecular scale detectable by coupled techniques.

\section{Experimental}

\subsection{Materials}

The commercial crystalline copper (II) acetate mono-hydrate $\mathrm{Cu}(\mathrm{Ac})_{2} \cdot \mathrm{H}_{2} \mathrm{O}$ $\left(\mathrm{Ac}=\mathrm{CH}_{3} \mathrm{COO}\right)$ was an ACS product of reagent grade ( $\left.>98 \%\right)$ and used without further purification.

\subsection{Apparatus}

The thermal decompositions of copper acetate were analyzed by various follow-up techniques: in-situ X-ray diffraction (XRD), thermogravimetry analysis (TGA), in-situ diffuse reflectance infrared Fourier transform spectroscopy (DRIFT) coupled to micro gas chromatography ( $\mu \mathrm{GC}$ ) and mass spectroscopy (MS).

\subsection{Methods}

\subsubsection{Thermal Analysis}

The X-ray diffraction of copper acetate monohydrate was performed using TUR-M62 diffractometer with copper anticathode $(\lambda=1.54 \AA), 34 \mathrm{kV}$ voltage and $25 \mathrm{~mA}$ current. The XRD patterns were acquired for $2 \theta$ angles ranging from $10^{\circ}$ to $70^{\circ}$, with $0.03^{\circ}$ steps. The XRD measurements were conducted in temperature programmed mode. For this purpose, Bruker D8 Advance diffractometer equipped with temperature programmed chamber was used. The XRD patterns were collected at temperatures ranging from $30^{\circ} \mathrm{C}$ to $400^{\circ} \mathrm{C}$ with heating rate of $10^{\circ} \mathrm{C} /$ min flowing air or Ar. After the heating, the solid decomposition products were analyzed at room temperature into the chamber. Corresponding diffractograms during the acetate decomposition were collected at $30^{\circ} \mathrm{C}, 110^{\circ} \mathrm{C}, 170^{\circ} \mathrm{C}$, $190^{\circ} \mathrm{C}, 250^{\circ} \mathrm{C}$ and $370^{\circ} \mathrm{C}$. Thermal decomposition of sample was carried out in a TGA thermogravimetry (series Q5000) of TA Instruments in a flowing air or argon atmosphere $\left(10 \mathrm{ml} \cdot \mathrm{min}^{-1}\right)$. Approximately, 2 - $3 \mathrm{mg}$ of sample was heated 
in an open platinum crucible at a rate of $15^{\circ} \mathrm{C} / \mathrm{min}$ up to $400^{\circ} \mathrm{C}$, incorporating a controlled rate thermal analysis program. To confirm the feasibility of comparing sample results by different techniques, TGA of $\mathrm{Cu}(\mathrm{Ac})_{2} \cdot \mathrm{H}_{2} \mathrm{O}$ and $\mathrm{Cu}(\mathrm{Ac})_{2} \cdot \mathrm{H}_{2} \mathrm{O}$ in $\mathrm{KBr}$ were tested and gave almost the same result for the same temperatures.

\subsubsection{In Situ DRIFT-GC and MS Coupled Measurements}

The in-situ experiments have been performed in a Vertex 70 Bruker IR spectrometer equipped with a one-pot sample compartment. The in situ setup provides all necessary gas in and outlets for flow control and allows temperature measurements. Mass flows were regulated using mass flow controllers (Bronkhorst). For DRIFTS, we used a controlled temperature reaction home-made chamber (7 $\mathrm{ml}$ ), smaller than high-temperature chamber from Harrick, fitted with ZnSe windows and a Praying Mantis diffuse reflection accessory (Harrick). Temperatures were directly measured in the center of the catalytic bed by mean of a 0.75 $\mathrm{mm} * 150 \mathrm{~mm}$ type $\mathrm{K}$ thermo-couple. The apparatus originality is due to its coupling mode: it is an IR spectrometer coupled with a mass spectrometer and gas phase chromatograph ( $\mu \mathrm{GC}-\mathrm{MS})$. This allows measurements in situ during a reaction under controlled atmosphere. The flow of gas is recovered at the outlet of the chamber and is brought to through a transfer rod to the $\mu$ GC-MS switchgear. The experiments are performed by a new coupled instrumentation obtained by miniaturized cell, a DRIFT spectroscopy, 3 micro gas chromatographs and a mass spectrometer. One of the present technique advantages is to allow data acquisition throughout the transformation on the solid material and on the produced gases simultaneously. The coupling with gas chromatography (gas molecule identification by mass spectrometry) makes possible to monitor continuously the emission of gas. These experimental steps are systematically carried out during the sample preparation for DRIFTS analysis. The QMS data shown here were corrected by the following $\mathrm{m} / \mathrm{z}$ values obtained by calibration: $\mathrm{CO}_{2}$ gas $(\mathrm{m} / \mathrm{z}=44), \mathrm{H}_{2} \mathrm{O}(\mathrm{m} / \mathrm{z}=18)$, acetic acid $(\mathrm{m} / \mathrm{z}=60)$ and acetone $(\mathrm{m} / \mathrm{z}=$ 43). The spectra are measured from 600 to $4000 \mathrm{~cm}^{-1}$ with a resolution of $4 \mathrm{~cm}^{-1}$ (15 spectra/second) and are directly collected by the computer. The reaction chamber is equipped with $\mathrm{ZnSe}$ windows and a gas flow of $10 \mathrm{~cm}^{3} \cdot \mathrm{min}^{-1}$ across the sample. The experiments are carried out from room temperature to $600^{\circ} \mathrm{C}$ $\left(15^{\circ} \mathrm{C} \cdot \mathrm{min}^{-1}\right)$, to avoid heating during high temperature studies, the chamber is equipped with a cooled double wall of water flow to control temperature. Samples are prepared by dilution (10 wt\%) with dry powder of potassium bromide $(\mathrm{KBr})$ or zinc selenide $(\mathrm{ZnSe})$ as a diluent. Different conditions of test are made to show the influence of the presence of water interaction with the diluent during the decomposition steps. Powders are milled together and then placed on the sample holder in the chamber. This cell is closed and purged with helium (10 $\mathrm{mL} / \mathrm{min}$ ) for 5 minutes, sufficient time to purge the small chamber. The desired gas is then introduced, with a purge of 5 minutes for each experimental conditions variation. All gases were used without further purification (He:Alphagaz 
2, >99.9999\%; Ar:Alphagaz 2, >99.9999\%; synthetic air Air Products, >99.9999\%). No reabsorption, especially water, has been observed by leaving $\mathrm{KBr}$ sample overnight under flow.

\section{Results}

\subsection{Study of Copper Acetate Decomposition by XRD and TGA}

In situ $\mathrm{XRD}$ profiles of $\mathrm{Cu}(\mathrm{Ac})_{2} \cdot \mathrm{H}_{2} \mathrm{O}$ under heat treatment at $30^{\circ} \mathrm{C}, 110^{\circ} \mathrm{C}$, $170^{\circ} \mathrm{C}, 190^{\circ} \mathrm{C}, 250^{\circ} \mathrm{C}$ and $370^{\circ} \mathrm{C}$ are showed by Figure 1 . Copper acetate monohydrate and copper acetate are both observed in the XRD profiles at room temperature and mainly $\mathrm{Cu}(\mathrm{Ac})_{2}$ at $110^{\circ} \mathrm{C}$ under air and $\mathrm{Ar}$. The decomposition of acetate species starts at $190^{\circ} \mathrm{C}$ and finishes before $250^{\circ} \mathrm{C}$ as shown by the acetate cristal disappearing on the XRD profile at $250^{\circ} \mathrm{C}$ under air and at $190^{\circ} \mathrm{C}$ under Ar. This compound, in opposition to other acetate as $\mathrm{Co}(\mathrm{Ac})_{2} \cdot 4 \mathrm{H}_{2} \mathrm{O}$ [16], do not melted during the dehydration step. Between $190^{\circ} \mathrm{C}$ and $250^{\circ} \mathrm{C}$, broad peaks appear in the range of $35^{\circ}-40^{\circ}$ of $2 \theta$. These profiles should correspond to intermediate species since copper oxides and copper are detected in XRD profiles further. According to heat treatment media, different oxides appear above $190^{\circ} \mathrm{C} . \mathrm{Cu}_{2} \mathrm{O}$ and $\mathrm{CuO}$ appear at $250^{\circ} \mathrm{C}$ and $370^{\circ} \mathrm{C}$ respectively under air. Whereas, these both oxides appear simultaneously under $\mathrm{Ar}$ and get transformed to $\mathrm{Cu}$ around $370^{\circ} \mathrm{C}$.

TGA/TGD curves of $\mathrm{Cu}(\mathrm{Ac})_{2} \cdot \mathrm{H}_{2} \mathrm{O}$ are shown in Figure 2. These studies confirm the two steps as presented mainly in the literature [5] [9] [12], one first step for dehydration then decarboxylation with differences according to heat media. The curves of copper acetate monohydrate decomposition obtained by TGA/DTG (Figure 2) display mainly two mass loss steps in the temperature range from $22^{\circ} \mathrm{C}$ to $400^{\circ} \mathrm{C}$, and one mass gain step in air. The corresponding data of mass changes are listed in Table 1 . The listed experimental values of first mass loss step agree with theoretical value (9.0\%) of absolute dehydration of $\mathrm{Cu}(\mathrm{Ac})_{2} \cdot \mathrm{H}_{2} \mathrm{O}$ under air and Ar. The second mass loss step was commonly attributed

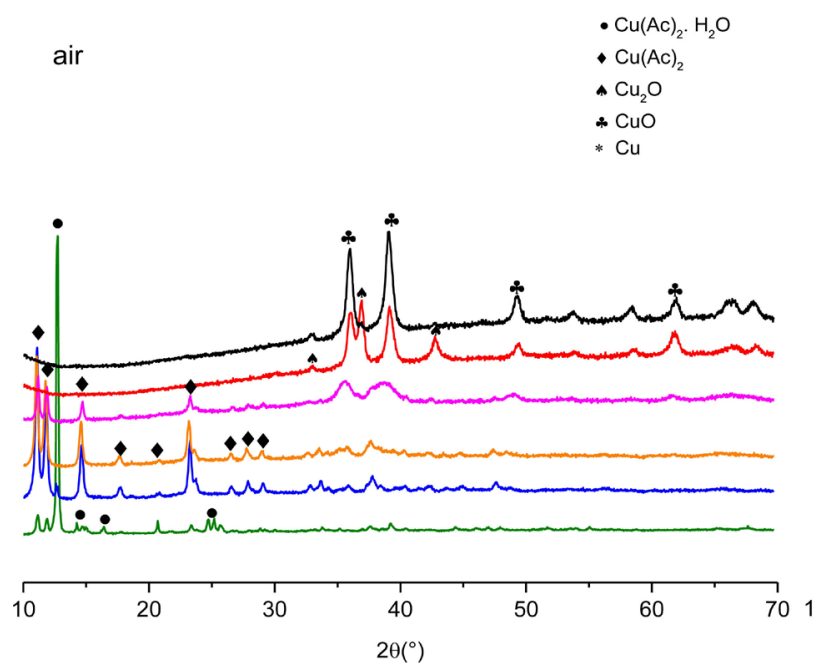

(a)

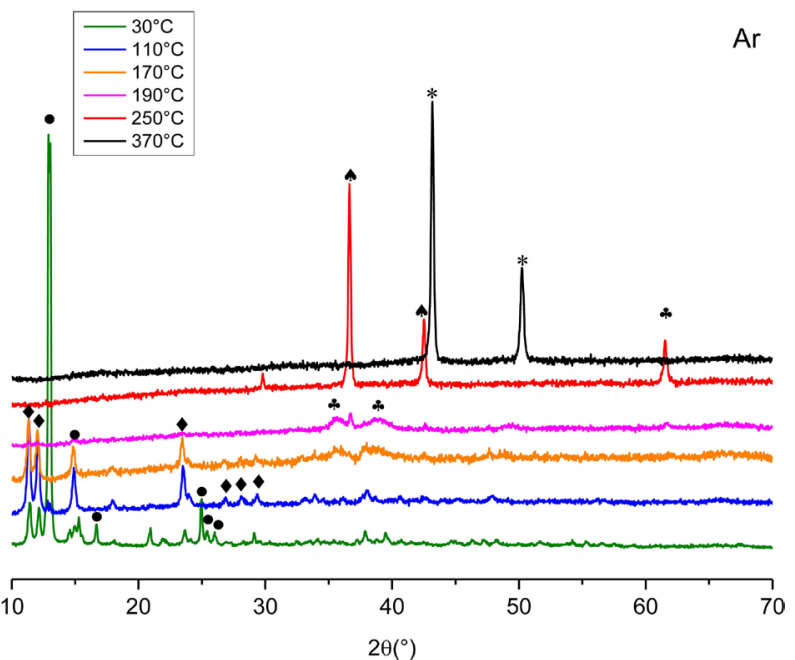

(b)

Figure 1. XRD patterns for copper acetate monohydrate thermal decomposition under air and Ar. 

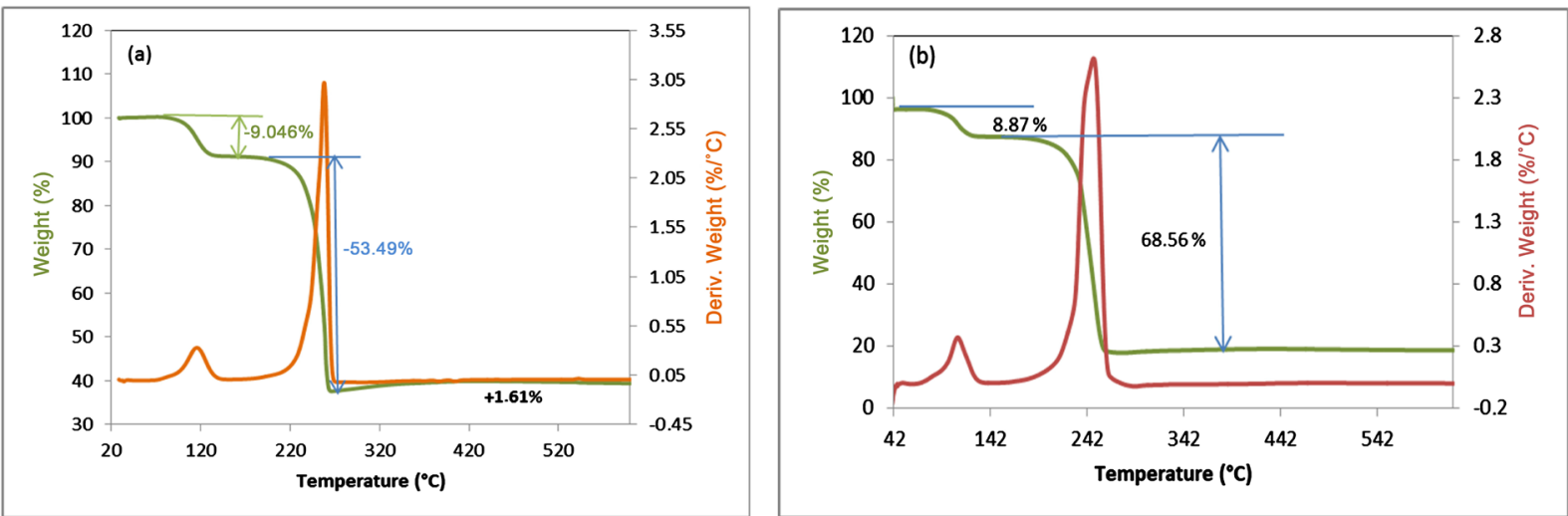

Figure 2. TGA and DTG curves for thermal decomposition of $\mathrm{Cu}(\mathrm{Ac})_{2} \cdot \mathrm{H}_{2} \mathrm{O}$ in air (a), in $\mathrm{Ar}(\mathrm{b})$.

Table 1. Mass changes of $\mathrm{Cu}(\mathrm{Ac})_{2} \cdot \mathrm{H}_{2} \mathrm{O}$ thermal decomposition under air and Ar.

\begin{tabular}{|c|c|c|c|c|}
\hline Step & & Temperature range $\left({ }^{\circ} \mathrm{C}\right)$ & Mass change (\%) & Theoretical mass change (\%) \\
\hline \multirow{3}{*}{ Air } & 1 & $100-170$ & -9.0 & -9.0 \\
\hline & 2 & $230-310$ & -53.5 & -55.1 \\
\hline & 3 & $310-600$ & +1.6 & +4 \\
\hline \multirow{2}{*}{$\mathrm{Ar}$} & 1 & $80-140$ & -8.9 & -9.0 \\
\hline & 2 & $200-275$ & -68.6 & -65.3 \\
\hline
\end{tabular}

to $\mathrm{Cu}(\mathrm{Ac})_{2}$ decomposition since the experimental value of mass loss under air for this step is consistent with the theoretical one $(-55.1 \%)$ [17]. The mass increase between 310 and $600^{\circ} \mathrm{C}$ is lower than theoretical value (4\%). $\mathrm{Cu}_{2} \mathrm{O}$ is only partially oxidized to $\mathrm{CuO}$ at $600^{\circ} \mathrm{C}$. According to XRD patterns, $\mathrm{Cu}(\mathrm{Ac})_{2}$ decomposition under Ar between $195^{\circ} \mathrm{C}$ and $275^{\circ} \mathrm{C}$ produce $\mathrm{Cu}_{2} \mathrm{O}$ and $\mathrm{CuO}$ which are reduced thereafter to $\mathrm{Cu}$ since the experimental value of the mass loss for steps was quite close to the theory value. Difference between theoretical and experimental values of mass gain under Ar could be explained by multi-crystal phase formation during heat treatment between $230^{\circ} \mathrm{C}$ and $310^{\circ} \mathrm{C}$. TGA seems to propose a relative simple phenomena for the degradation of $\mathrm{Cu}(\mathrm{Ac})_{2} \cdot \mathrm{H}_{2} \mathrm{O}$ but do not explain reaction mechanism. Thus, solid and emitted gases must be analyzed simultaneously in situ to identify intermediate species and then elucidate $\mathrm{Cu}(\mathrm{Ac})_{2} \cdot \mathrm{H}_{2} \mathrm{O}$ thermal decomposition mechanism. According to TGA and XRD in situ results, $\mathrm{Cu}(\mathrm{Ac})_{2} \cdot \mathrm{H}_{2} \mathrm{O}$ thermal decomposition reaction could be given broadly as follow without consideration of organic moieties because of lack of corresponding data:

1) $\mathrm{Cu}\left(\mathrm{CH}_{3} \mathrm{COO}\right)_{2} \cdot \mathrm{H}_{2} \mathrm{O} \rightarrow \mathrm{CuO}$ under air;

2) $\mathrm{Cu}\left(\mathrm{CH}_{3} \mathrm{COO}\right)_{2} \cdot \mathrm{H}_{2} \mathrm{O} \rightarrow \mathrm{Cu}$ under $\mathrm{Ar}$.

\subsection{Analysis of Overall DRIFT Spectra Evolution during Copper Acetate Decomposition: Relation between Reaction Course and Modifications at the Molecular Scale}

In this study, DRIFT analysis monitor phenomena occurring at the molecular 
scale during thermal decomposition reaction. To achieve this goal, main spectral regions were identified then we focused on a limited number of spectra for $\mathrm{Cu}(\mathrm{Ac})_{2} \cdot \mathrm{H}_{2} \mathrm{O}$ decomposition at specific temperature. The in situ DRIFT spectra of $\mathrm{Cu}(\mathrm{Ac})_{2} \cdot \mathrm{H}_{2} \mathrm{O}$ from room temperature to $410^{\circ} \mathrm{C}$ in air and in $\mathrm{He}$, are showed in Figure 3, and peaks assignment are listed in Table 2 in agreement with Z. Lin and Mathey [12] [14].

\subsubsection{Dehydration Step and Water Influence on DRIFT Spectra}

As shown in Figure 4, absorptive peak of $\mathrm{O}-\mathrm{H}$ bond of water $\left(3380 \mathrm{~cm}^{-1}\right)$ and free $\mathrm{O}-\mathrm{H}\left(3585 \mathrm{~cm}^{-1}\right)$ distinctly weaken from $100^{\circ} \mathrm{C}$ approximately (beginning of $\mathrm{H}_{2} \mathrm{O}$ desorption from precursor solid surface) and corresponds to the dehydration of $\mathrm{Cu}(\mathrm{Ac})_{2} \cdot \mathrm{H}_{2} \mathrm{O}$. The results from the DRIFT spectra complete the TGA/DTG results and show slower leaving of $\mathrm{OH}$ moieties under air than under inert gas. The small amount of water staying on copper is able to change the mechanism of acetate decomposition and this issue will be discussed later.

\subsubsection{Decarboxylation/Decomposition Step}

DRIFT domain spectrum between 1150 and $1850 \mathrm{~cm}^{-1}$ contained characteristic peak of bidentate/bridged copper acetate bonds vibration mainly. During decomposition course, we observed intensity variation and shift position of peak intensities in that spectra region (Figure 5). Consistent with other references in literature [18] [19] [20] [21], DRIFT bands are observed for copper acetate dehydrate at $1608,1580,1441$, and $1362 \mathrm{~cm}^{-1}$. The carboxylate symmetric stretch is located as two bands at 1441 and $1362 \mathrm{~cm}^{-1}$, while the asymmetric one is observed at 1608 and $1580 \mathrm{~cm}^{-1}$. Intensities of listed peaks are influenced by temperature variation according to moisture level on the substrate and configuration of organic moieties. Above $200^{\circ} \mathrm{C}$ under air and Ar, bands of asymmetric stretching acetate at 1608 are cleaved to main bands at 1620 and $1580 \mathrm{~cm}^{-1}$ according to bidentate-monodentate transformation [22] (Figure 5). The diffractograms

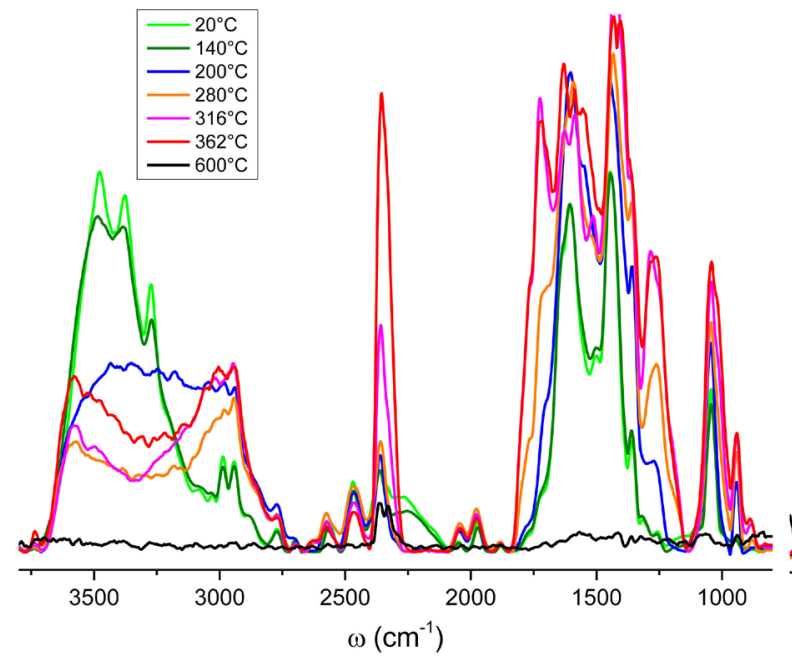

(a)

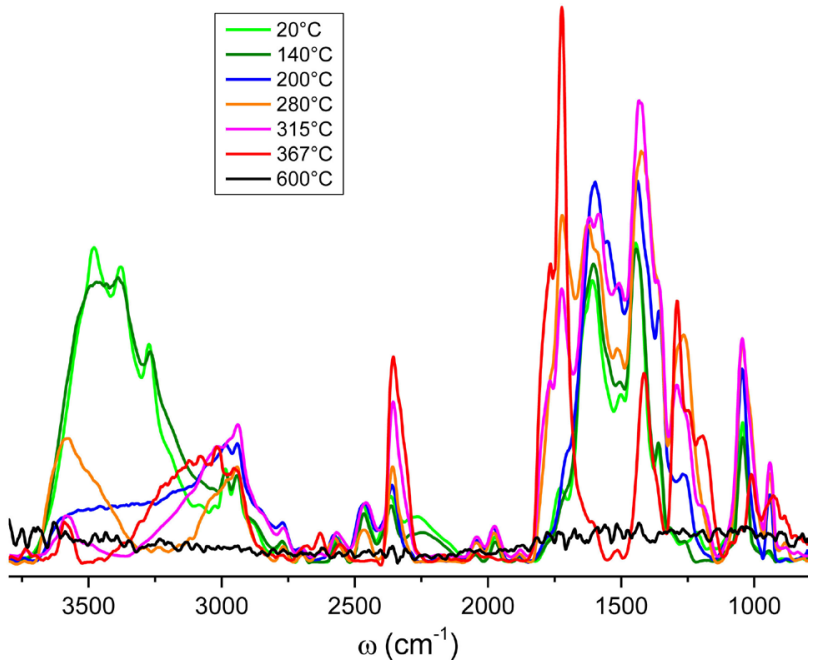

(b)

Figure 3. In situ DRIFT of $\mathrm{Cu}(\mathrm{Ac})_{2} \cdot \mathrm{H}_{2} \mathrm{O}$ in $\mathrm{KBr}$ under air (a) and $\mathrm{Ar}(\mathrm{b})$ between 4000 and $800 \mathrm{~cm}^{-1}$. 
Table 2. Assignments of DRIFT spectra of $\mathrm{Cu}(\mathrm{Ac})_{2} \cdot \mathrm{H}_{2} \mathrm{O}$.

\begin{tabular}{|c|c|}
\hline Wavenumber $\left(\mathrm{cm}^{-1}\right)$ & Assignment \\
\hline 3585 & $\mathrm{O}-\mathrm{H}$ stretching in acetic acid/ $\mathrm{CO}_{2}$ gas \\
\hline $3478-3373$ & $\mathrm{O}-\mathrm{H}$ stretching in water \\
\hline $3000[18]$ & $\mathrm{CH}_{3}$ asymmetric stretch in acetone \\
\hline 2989,2942 & $\mathrm{C}-\mathrm{H}$ stretching in methyl \\
\hline 2360 & $\mathrm{CO}_{2}$ gas \\
\hline $1715[19]$ & $\mathrm{C}=\mathrm{O}$ stretching in acetone \\
\hline $1722[20]$ & $\mathrm{C}=\mathrm{O}$ stretching in acetic acid \\
\hline 1608 & $\mathrm{C}=\mathrm{O}$ asymmetric stretching \\
\hline 1620 & $\mathrm{O}-\mathrm{H}$ in $\mathrm{H}_{2} \mathrm{O}$, \\
\hline $1613[21]$ & $\mathrm{Cu}-\mathrm{H}$ stretching in $\mathrm{CH}_{3}-\mathrm{CuH}^{-}$ \\
\hline $1580-1550$ & $\mathrm{C}=\mathrm{O}$ asymmetric stretching \\
\hline $1573[20]$ & $\mathrm{O}-\mathrm{H}$ stretching in chemisorbed $\mathrm{H}_{2} \mathrm{O}$ \\
\hline $1450-1430$ & $\mathrm{C}=\mathrm{O}$ symmetric stretching \\
\hline $1375(1362)[20]$ & $\mathrm{C}=\mathrm{O}$ symmetric stretching \\
\hline 1355 & $\mathrm{C}-\mathrm{H}$ bending in methyl \\
\hline $1243[20]$ & $\mathrm{C}-\mathrm{OH}$ stretching in acetic acid \\
\hline $1203[21]$ & $\mathrm{CH}_{3}-\mathrm{Cu}, \mathrm{CH}_{3}$ deform \\
\hline $1051-1033$ & $\mathrm{C}-\mathrm{CH}$ framework vibration \\
\hline 944 & $\mathrm{C}-\mathrm{O}$ stretching in acetic acid \\
\hline $1012[21]$ & $\mathrm{CH}_{3}-\mathrm{CuH}, \mathrm{CH}_{3}$ deform \\
\hline $668-682$ & $\mathrm{CO}_{2}$ gas \\
\hline $648[21]$ & $\mathrm{CH}_{3}-\mathrm{Cu}, \mathrm{CH}_{3}$ rock \\
\hline
\end{tabular}

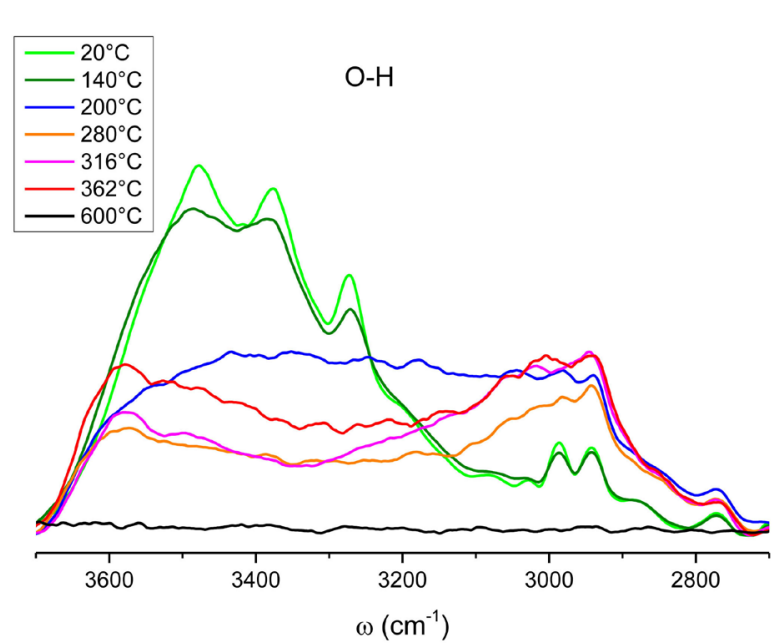

(a)

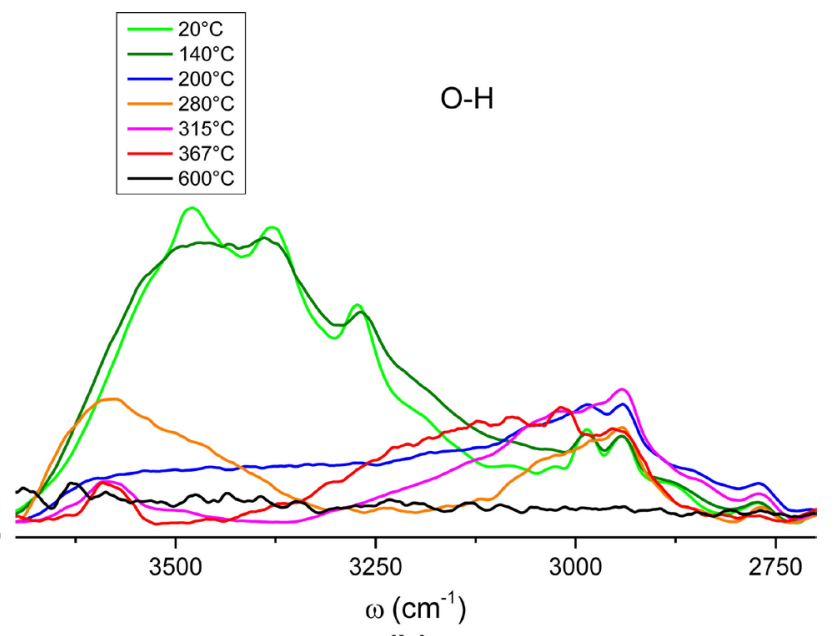

(b)

Figure 4. In situ DRIFT of $\mathrm{Cu}(\mathrm{Ac})_{2} \cdot \mathrm{H}_{2} \mathrm{O}$ in $\mathrm{KBr}$ under air (a) and $\mathrm{Ar}(\mathrm{b})$ between 3700 and $2700 \mathrm{~cm}^{-1}$. 


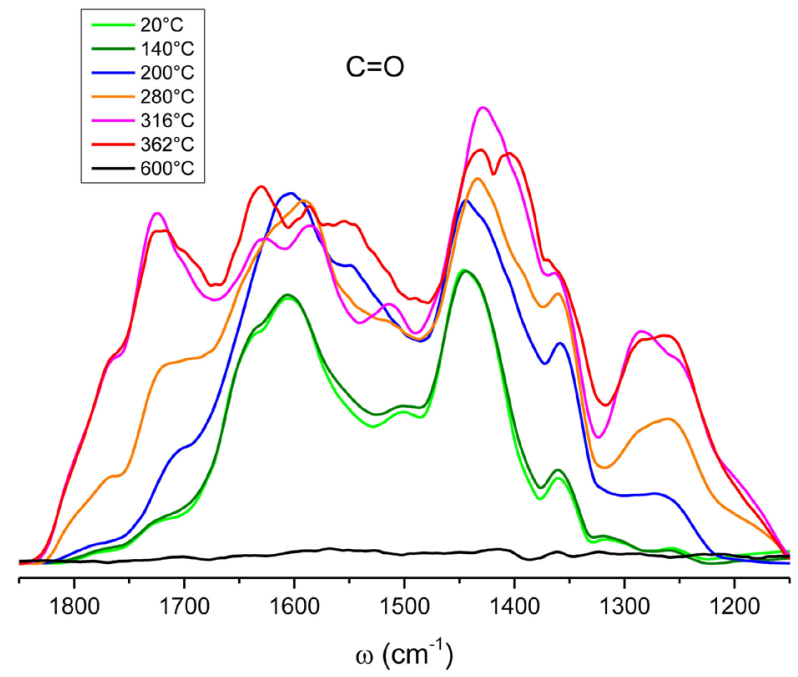

(a)

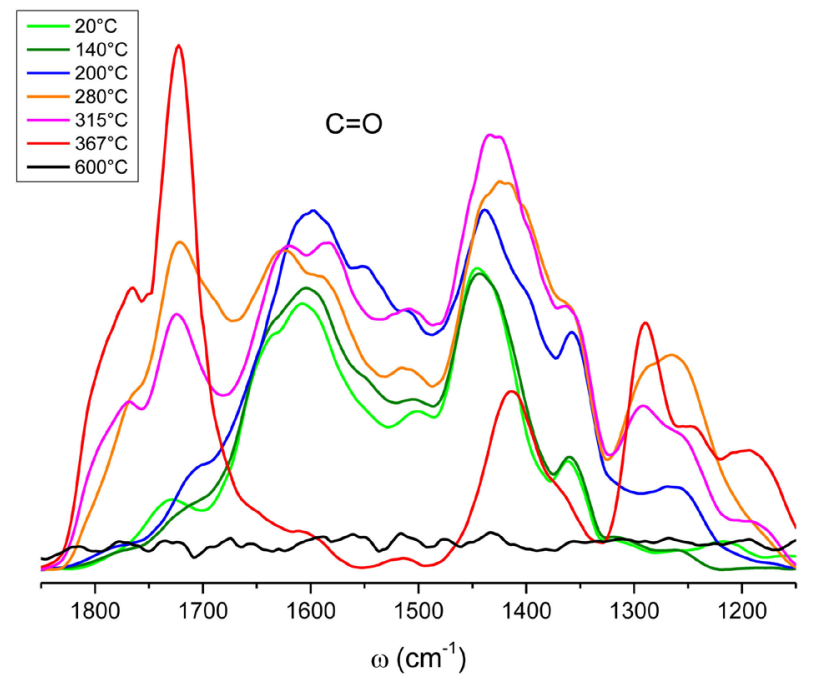

(b)

Figure 5. In situ DRIFT of ${ }^{1} \mathrm{Cu}(\mathrm{Ac})_{2} \cdot \mathrm{H}_{2} \mathrm{O}$ in $\mathrm{KBr}$ under air (a) and $\mathrm{Ar}(\mathrm{b})$ between 1850 and $1150 \mathrm{~cm}^{-1}$.

of hydrated $\mathrm{Cu}(\mathrm{Ac})_{2}$ (Figure 1) is described as bidentate acetate in the range of $35^{\circ}$ and $40^{\circ}$ between $190^{\circ} \mathrm{C}$ and $250^{\circ} \mathrm{C}$. Mixed with $\mathrm{KBr}$, the bidentate function is sensitive to $\mathrm{H}_{2} \mathrm{O}-\mathrm{Cu}$ bond length and carboxylate ligands are transformed from bidentate to monodentate species. This structure enhances water hooking on the neighborhood of carboxylate [22] at $1573 \mathrm{~cm}^{-1}$, [20]. Dehydration step is quite similar under $\mathrm{Ar}$ and air: specific bands of acetate ligands of $\mathrm{Cu}(\mathrm{Ac})_{2}$ at 1608,1441 and $1362 \mathrm{~cm}^{-1}$ increase from $20^{\circ} \mathrm{C}$ until $280^{\circ} \mathrm{C}$ under air and $315^{\circ} \mathrm{C}$ under Ar (Figure 5). Once this step is achieved, new bands at 1722 and 1260 $\mathrm{cm}^{-1}$ referring to $\mathrm{C}=\mathrm{O}$ and $\mathrm{C}-\mathrm{OH}$ stretch respectively in acetic acid [20] appear under air and Ar similarly. A main difference according heat treatment media is reported during this stage. Absorptive peaks at 1608 and $1442 \mathrm{~cm}^{-1}$ maintain rising intensity till $316^{\circ} \mathrm{C}$ than fall at $600^{\circ} \mathrm{C}$ under air. For inert gas, the latest bands disappeared between $315^{\circ} \mathrm{C}$ and $367^{\circ} \mathrm{C}$ with an increase of stretching bonds of acetic acid until $367^{\circ} \mathrm{C}$ (Figure 5). This observation reveals that acetate ligands start to decompose earlier under Ar and are converted to adsorbed acetic acid mainly, while, acetate ligands still bonded to copper metallic center during decomposition step under air. With TGA alone, it wasn't possible to prove the latest conclusion to assess differences in reaction mechanism under air and inert gas.

Figure 6 shows variation of peaks intensity referring to $\mathrm{C}-\mathrm{CH}$ and $\mathrm{C}-\mathrm{O}$ at 1044 and $942 \mathrm{~cm}^{-1}$ [23] respectively. These two bands increase from 20 to $367^{\circ} \mathrm{C}$ under air than fall by the end of heat treatment. $\mathrm{C}-\mathrm{CH}$ and $\mathrm{C}-\mathrm{O}$ bonds decompose earlier under Ar since relative bands turn before $367^{\circ} \mathrm{C}$. This observation illustrates that $\mathrm{CH}_{3} \mathrm{COO}^{-}$group bonded to metallic center as acetate ligand is converted to adsorbed acetic acid under Ar (Figure 5) before its complete decomposition after $367^{\circ} \mathrm{C}$. $\mathrm{CH}_{3} \mathrm{COO}^{-}$bonds are strengthened within heat treatment at dehydration and decarboxylation stages according to monodentate-bidentate/bridged transition. According to Campbell and Sharrock [24] [25] binuclear metal centers of copper acetate (II) were proposed to explain com- 
pound structure according to NMR signal multiplicity. Mononuclear metal centers are bridged to stabilize electronic deficit on $\mathrm{Cu}$ metallic center for $\mathrm{Cu}$ acetate monohydrate. Figure 6 stresses this conclusion since carboxylate bonds are strengthened by peaks rise at 1044 and $942 \mathrm{~cm}^{-1}$ in the range of $20^{\circ} \mathrm{C}$ and $315^{\circ} \mathrm{C}$.

Gaseous products as $\mathrm{CO}_{2}$, acetic acid, acetone and ethanol are also detected in the infrared chamber. These volatile products have been proposed in literature [5] [13], which is matched with the present results. We coupled DRIFT with $\mu$ GC-MS to follow dynamic volatile species emission during decomposition reaction. Characteristic species detected by coupled $\mu \mathrm{GC} / \mathrm{MS}$ are $\mathrm{CO}_{2}$ gas $(\mathrm{m} / \mathrm{z}=44)$, $\mathrm{H}_{2} \mathrm{O}(\mathrm{m} / \mathrm{z}=18)$, acetic acid $(\mathrm{m} / \mathrm{z}=60)$ and acetone $(\mathrm{m} / \mathrm{z}=43)$. Kinetic gas products emission is recorded within temperature increase and reported by Figure 7.

According to the quantification by injection pulses (Figure 8), the formation of $\mathrm{CO}_{2}$ corresponds to $88 \%$ of amount of carbon from acetate under air and only $15 \%$ under inert gas. Both moieties of acetate $\left(\mathrm{CH}_{3}^{-}\right.$and $\left.\mathrm{COO}^{-}\right)$were mainly

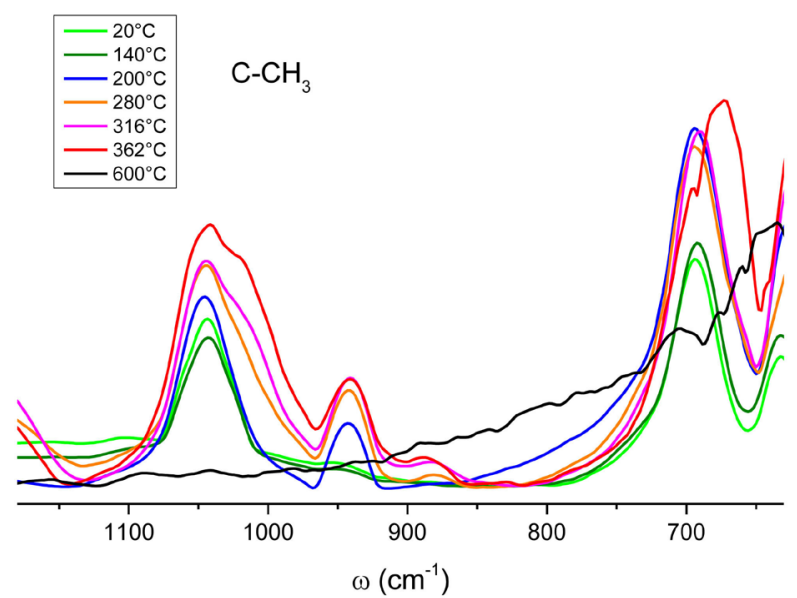

(a)

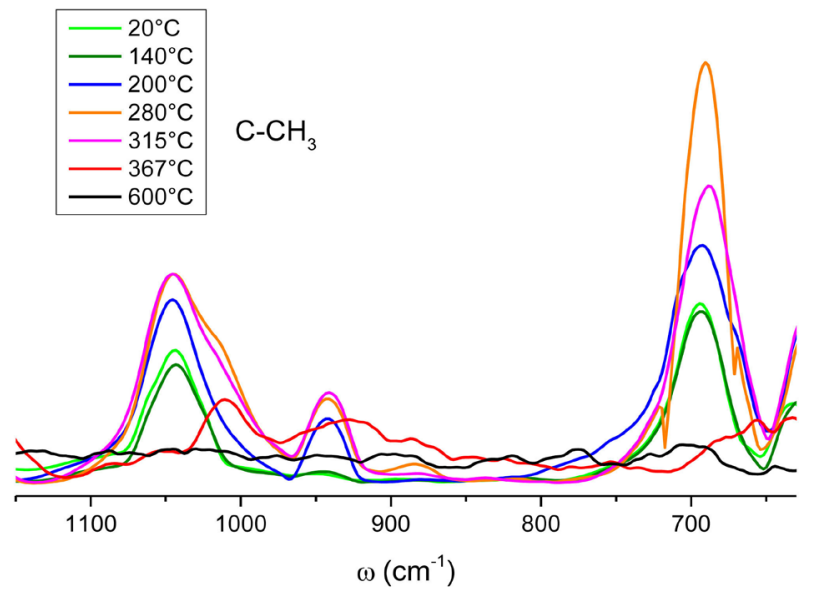

(b)

Figure 6. In situ DRIFT of $\mathrm{Cu}(\mathrm{Ac})_{2} \cdot \mathrm{H}_{2} \mathrm{O}$ in $\mathrm{KBr}$ under air (a) and $\mathrm{Ar}(\mathrm{b})$ between 1150 and $850 \mathrm{~cm}^{-1}$.

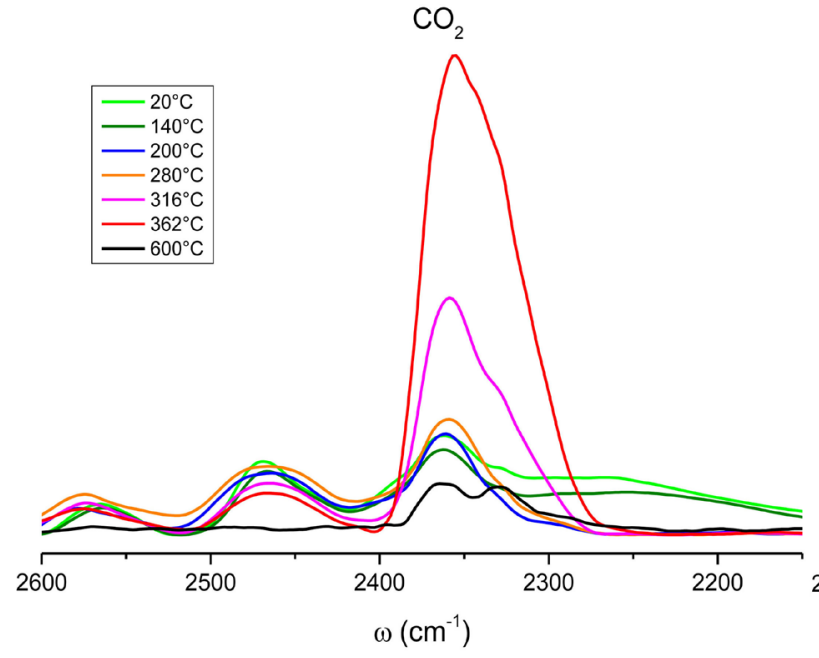

(a)

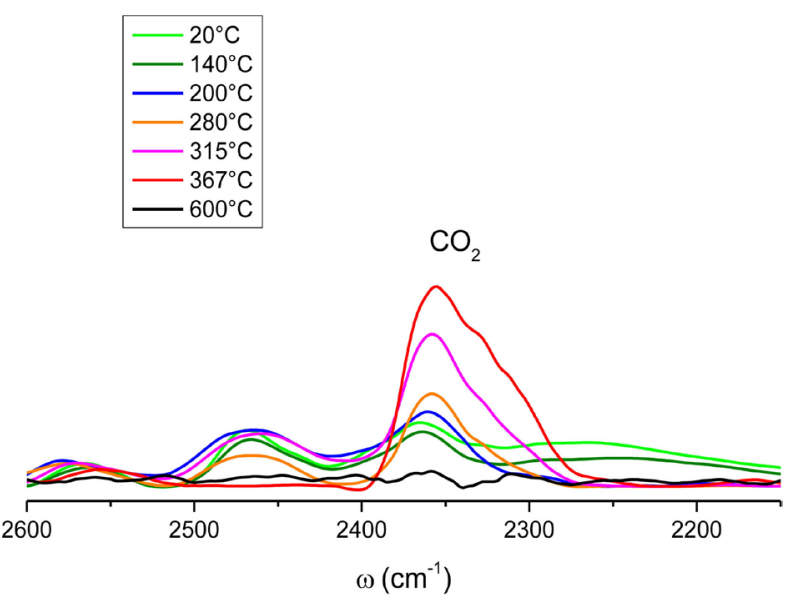

(b)

Figure 7. In situ DRIFT of $\mathrm{Cu}(\mathrm{Ac})_{2} \cdot \mathrm{H}_{2} \mathrm{O}$ in $\mathrm{KBr}$ under air (a) and $\mathrm{Ar}(\mathrm{b})$ between 2600 and $2150 \mathrm{~cm}^{-1}$. 
oxidized under air but the decomposition of acetate involves the creation of intermediate compounds which is mainly acetic acid under $\mathrm{Ar}$ (acetone and ethanol are formed at minor). According to DRIFT (Figure 5) and GC-MS (Figure 7) analysis, $\mathrm{Cu}(\mathrm{Ac})_{2}$ ligands are decomposed in both conditions (air or inert gas) with some similar intermediate species oxidized only under air. The same observation could be made for peak evolution at $2361 \mathrm{~cm}^{-1}$ related to vibration modes of $\mathrm{CO}_{2}$ gas bonds (Figure 8). We examined the intensity of some characteristic peaks within temperature. Figure 9 shows the variation of peaks intensity corresponding to $\mathrm{O}-\mathrm{H}$ stretching in water, $\mathrm{C}=\mathrm{O}$ stretching, $\mathrm{CO}_{2}$ gas and $\mathrm{C}-\mathrm{CH}_{3}$ framework vibration mode. This follow-up is used to monitor, within time and temperature, similarly to TGA analysis but with more accurate information than relative mass detection.
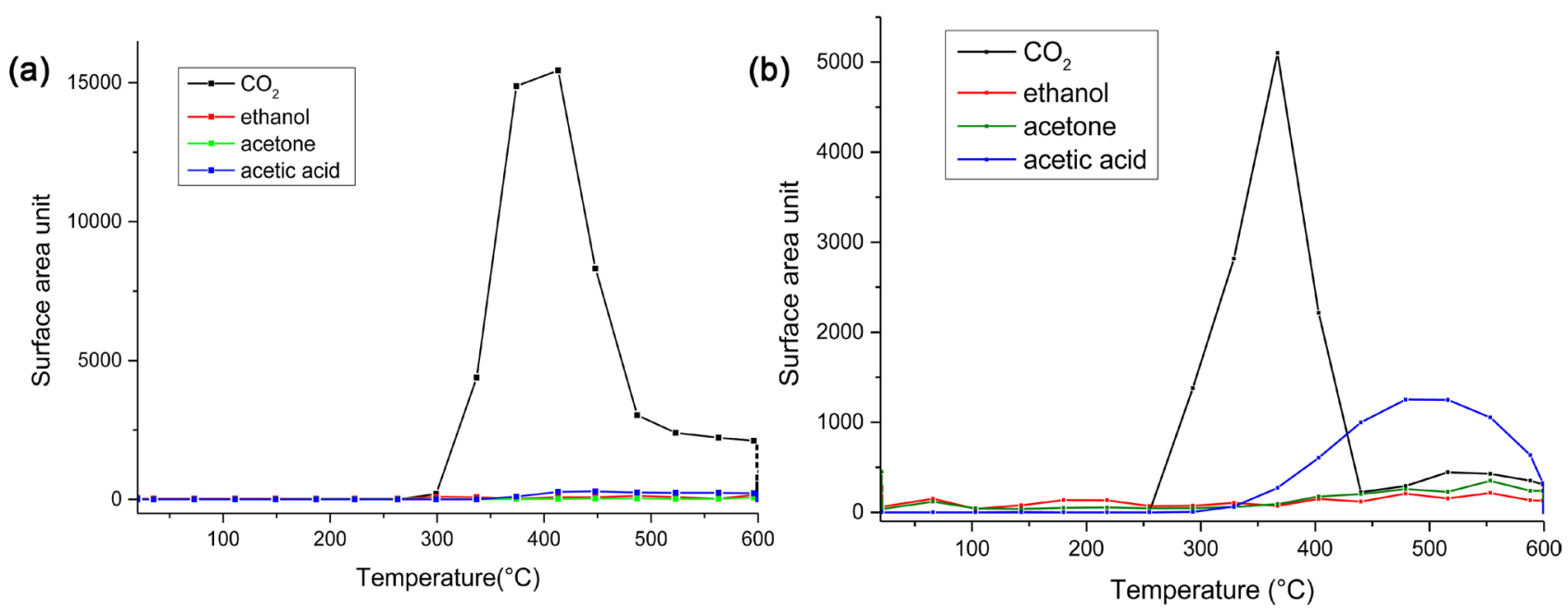

Figure 8. Gas emission quantification by $\mu$ GC-MS during $\mathrm{Cu}(\mathrm{Ac})_{2} \cdot \mathrm{H}_{2} \mathrm{O}$ decomposition under air (a) and $\mathrm{Ar}(\mathrm{b})$.

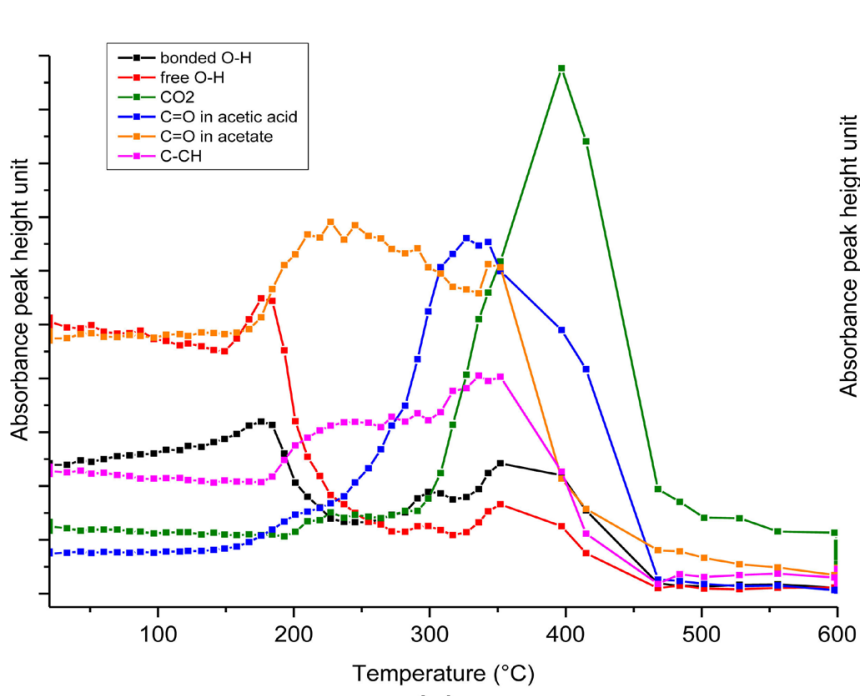

(a)

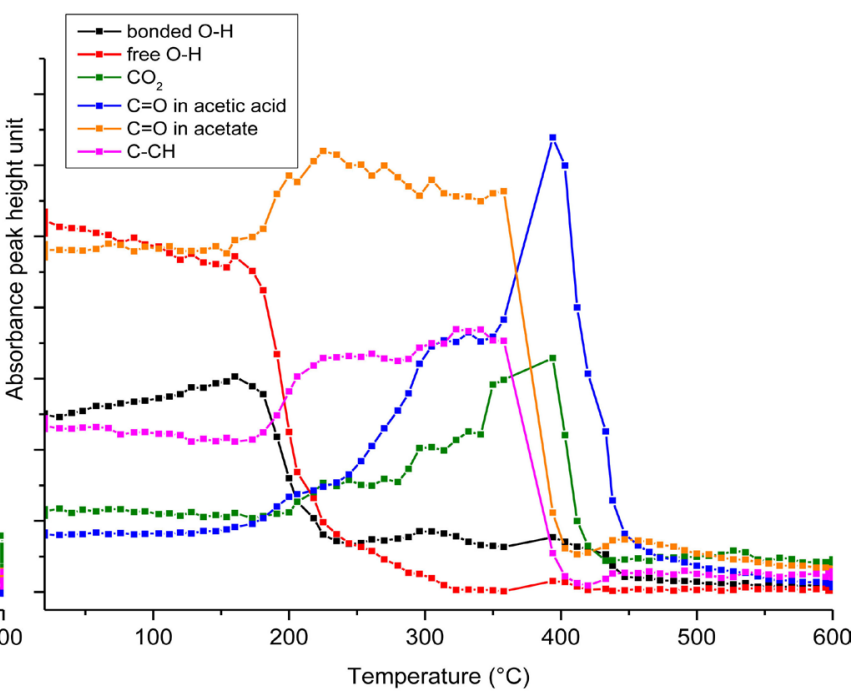

(b)

Figure 9. Bands intensities evolution of in situ DRIFT spectra within temperature for bonded O-H ( $\left.3585 \mathrm{~cm}^{-1}-\mathrm{black}\right)$, free O-H (3380 $\mathrm{cm}^{-1}$-red), $\mathrm{CO}_{2}$ gas $\left(2360 \mathrm{~cm}^{-1}\right.$-green $), \mathrm{C}=\mathrm{O}$ in acetic acid $\left(1722 \mathrm{~cm}^{-1}\right.$-blue $), \mathrm{C}=\mathrm{O}$ asymmetric $\left(1608 \mathrm{~cm}^{-1}\right.$-orange $)$ and $\mathrm{C}-\mathrm{CH}\left(1044 \mathrm{~cm}^{-1}\right.$ - purple) of $\mathrm{Cu}(\mathrm{Ac})_{2} \cdot \mathrm{H}_{2} \mathrm{O}$ in $\mathrm{KBr}$ under air (a) and $\mathrm{Ar}(\mathrm{b})$. 


\section{Discussion}

Scheme 1 (in annex section) describes mechanistic dynamic steps during thermal decomposition under air and Ar leading to $\mathrm{CuO}$ and $\mathrm{Cu}$ respectively as solid with emission of $\mathrm{H}_{2} \mathrm{O}, \mathrm{CO}_{2}, \mathrm{CH}_{3} \mathrm{COOH}, \mathrm{H}_{2}$ [26] (according reaction media) and coke deposit [27]. On Scheme 1, structures 1 and 2 describe binuclear complex dehydration step. XRD patterns confirm TGA results concerning dehydration process. $\mathrm{H}_{2} \mathrm{O}$ desorption ends at $170^{\circ} \mathrm{C}$ under air and at $140^{\circ} \mathrm{C}$ under $\mathrm{Ar}$ according to thermal analysis in agreement with XRD patterns (diffractograms pic of copper acetate monohydrate disappeared before $170^{\circ} \mathrm{C}$ ) and DRIFT analysis as shown by Figure 4 . Structure transition $1 \rightarrow 2$ could be traduced by the following reaction Equation (1):

$2 \mathrm{Cu}\left(\mathrm{CH}_{3} \mathrm{COO}\right)_{2} \cdot \mathrm{H}_{2} \mathrm{O} \rightarrow 2 \mathrm{Cu}\left(\mathrm{CH}_{3} \mathrm{COO}\right)_{2}+2 \mathrm{H}_{2} \mathrm{O} \quad\left\{\begin{array}{l}20^{\circ} \mathrm{C}-170^{\circ} \mathrm{C} \text { under air } \\ 20^{\circ} \mathrm{C}-140^{\circ} \mathrm{C} \text { under } \mathrm{Ar}\end{array}\right.$

According to TGA data, thermal decomposition of $\mathrm{Cu}(\mathrm{Ac})_{2} \cdot \mathrm{H}_{2} \mathrm{O}$ ends at $310^{\circ} \mathrm{C}$ under air and $275^{\circ} \mathrm{C}$ under Ar. Nevertheless, $\mathrm{Cu}(\mathrm{Ac})_{2} \cdot \mathrm{H}_{2} \mathrm{O}$ signal on XRD patterns falls before, in the range of $190^{\circ} \mathrm{C}$ and $250^{\circ} \mathrm{C}$ (before $190^{\circ} \mathrm{C}$ under Ar) with appearance of broad peaks at $2 \theta$ ranging from $35^{\circ}$ to $40^{\circ}$ (Figure 1 ). Crucially, we observe an increase of C-O stretching bond intensity at $944 \mathrm{~cm}^{-1}$ (Figure 6) from $20^{\circ} \mathrm{C}$ to $310^{\circ} \mathrm{C}$ approximately then a decrease reaching $600^{\circ} \mathrm{C}$. The correlation between the latest observations on TGA, XRD and DRIFT results is worth noting as it concludes on complex transition $2 \rightarrow 3$ (Scheme 1): acetate ligands are shifted from bidentate to monodentate species. Figure 9 confirms this conclusion: $\mathrm{C}=\mathrm{O}$ bands $\left(1608\right.$ and $1718 \mathrm{~cm}^{-1}$ ) increased within temperature simultaneously with desorption of $\mathrm{H}_{2} \mathrm{O}$ moieties (fall of 3380 and 3585 $\mathrm{cm}^{-1}$ signal by the end of dehydration steps under Ar and air). Structure 3 is proposed according to $\mathrm{H}_{2} \mathrm{O}$ desorption step for carboxylic acid ketonization on acid-base pairs of $\mathrm{TiO}_{2}$ [28]. $\mathrm{H}_{2} \mathrm{O}$ desorption involves $\mathrm{C}-\mathrm{C}$ coupling between 1 -hydroxyl enolate and co-adsorbed acetate to form $\alpha$-hydroxy $\gamma$-carboxy alkoxide. An XRD pattern (Figure 1) confirms $\mathrm{Cu}_{2} \mathrm{O}$ lattice formation under air and Ar starts at $190^{\circ} \mathrm{C}-250^{\circ} \mathrm{C}$. Thus, once dehydration step is achieved, $\mathrm{Cu}_{2} \mathrm{O}$ network appears $(2 \rightarrow 3$ transition in Scheme 1$)$.

As mentioned by GC-MS data measurements (Figure 7), $\mathrm{CO}_{2}$ detection on gas phase starts at $300^{\circ} \mathrm{C}$ under air and $250^{\circ} \mathrm{C}$ under $\mathrm{Ar}$ and reaches maximal values at $413^{\circ} \mathrm{C}$ and $367^{\circ} \mathrm{C}$ respectively. Meanwhile, $\mathrm{CO}_{2}$ is detected on precursor surface from $200^{\circ} \mathrm{C}$ (both Ar and air). Transition $3 \rightarrow 4$ on Scheme 1 illustrates $\mathrm{CO}_{2}$ adsorption on cupric center than its desorption for transition $4 \rightarrow 5$. Transition $3 \rightarrow 5$ is resumed by Equation (2) as bellow:

$$
2 \mathrm{Cu}\left(\mathrm{CH}_{3} \mathrm{COO}\right)_{2} \rightarrow(\mathrm{CuO})_{2}\left(1-\mathrm{CO}\left(\mathrm{CH}_{3}\right) \mathrm{CH}_{2}\right)_{2}+2 \mathrm{CO}_{2} \quad\left\{\begin{array}{l}
300^{\circ} \mathrm{C}-480^{\circ} \mathrm{C} \text { under air } \\
250^{\circ} \mathrm{C}-450^{\circ} \mathrm{C} \text { under } \mathrm{Ar}
\end{array}\right.
$$

Air media promotes complete oxidation of acetate ligands to $\mathrm{CO}_{2}$ and $\mathrm{H}_{2} \mathrm{O}$ (transition $5 \rightarrow 6^{\prime}$ ). We note an involving rate of adsorbed acetic acid on $\mathrm{Cu}_{2} \mathrm{O}$ (Figure 9(a)) surface under air without its detection by GC-MS. This is ex- 
plained adsorbed acetic acid oxidation to $\mathrm{CO}_{2}$ and $\mathrm{H}_{2} \mathrm{O}$. Indeed, evolution of hydroxyl bands on Figure 4(a) and Figure 9(a) illustrates a signal rise from $280^{\circ} \mathrm{C}$ to $360^{\circ} \mathrm{C}$, which is matching mechanism transition for the final step under air and $\mathrm{Cu}_{2} \mathrm{O}$ turns into $\mathrm{CuO}$ as latest crystalline phase (fig. a).

The transition $2 \rightarrow 3$ " on Scheme 1 is proposed as one step decomposition of $\mathrm{Cu}(\mathrm{Ac})_{2} \cdot \mathrm{xH}_{2} \mathrm{O}(\mathrm{x} \neq 0)$ to acetic acid and $\mathrm{Cu}$ under Ar without $\mathrm{CO}_{2}$ desorption and copper oxide intermediates. $\mathrm{H}_{2} \mathrm{O}$ is essential for this transition that its equilibrium is rather shifted for compound 2.

A notable difference is identified for thermal decomposition under Ar after $300^{\circ} \mathrm{C}$ compared to the same one under air. Acetic acid is detected by GC-MS (Figure $7(\mathrm{~b})$ ) from $340^{\circ} \mathrm{C}$ and reaches its maximum at $500^{\circ} \mathrm{C}$. Its desorption was also predicted by DRIFT spectra (Figure 5(b) and Figure 9(b)) since $\mathrm{C}=\mathrm{O}$ stretching band at $1722 \mathrm{~cm}^{-1}$ increases from 340 until $400^{\circ} \mathrm{C}$, thus, $\mathrm{CH}_{3} \mathrm{COOH}$ was adsorbed on $\mathrm{Cu}_{2} \mathrm{O}$ surface before its desorption. Transition $5 \rightarrow 9$ describe acetic acid desorption. This transition is deeply influenced by water adsorption on copper atoms. Residual $\mathrm{H}_{2} \mathrm{O}$ moieties in $\mathrm{KBr}$, since its hygroscopic property, oxidize ligands by nucleophilic substitution. This reaction involves $\mathrm{C}-\mathrm{O}$ coupling between 1-hydroxyl enolate and coordinated residual $\mathrm{H}_{2} \mathrm{O}$ to form $\alpha$-hydroxy alkoxide. The latest intermediate is converted to $\mathrm{Cu}-\mathrm{CH}_{3} \mathrm{COOH}$ and $\mathrm{Cu}-\mathrm{CH}_{3}$ [28] (Scheme 1.6 $\rightarrow$ 9). On Figure 4, OH bands fall are more noticed under Ar rather than under air which confirms the latest hypothesis since $\mathrm{H}_{2} \mathrm{O}$ was consumed to form acetic acid. Figure 9(b) stresses this observation: no hydroxyl bands increase after $300^{\circ} \mathrm{C}$ under Ar contrarily to air. Ligands decomposition under $\mathrm{Ar}$ involves $\mathrm{Cu}_{2} \mathrm{O}$ phase formation. Copper oxide turns to $\mathrm{Cu}$ between $250^{\circ} \mathrm{C}$ and $370^{\circ} \mathrm{C}$ with desorption of $\mathrm{CO}_{2}$ as described by Figure 9 (b) plot.

To assess the influence of adsorbed water in mechanism reaction, two types of diluent were tested under $\mathrm{Ar}: \mathrm{KBr}$ on one hand with hygroscopic property and $\mathrm{ZnSe}$ on the other hand. When the diluent is hygroscopic, $\mathrm{C}=\mathrm{O}$ bands shifted during decomposition process (Figure 5) When the diluent does not interact with water as $\mathrm{ZnSe}, \mathrm{C}=\mathrm{O}$ bands are kept in the same position during heating. Mixed with $\mathrm{ZnSe}$, acetate is bonded to copper as bidentate ligands during dehydration and decomposition steps under air and inert gas. Moreover, gaseous products for $\mathrm{Cu}(\mathrm{Ac})_{2} \cdot \mathrm{H}_{2} \mathrm{O}$ under $\mathrm{Ar}$ in $\mathrm{ZnSe}$ are different from similar reaction in $\mathrm{KBr}$ : GC-MS shows formation of acetone at the same level as acetic acid in addition to $\mathrm{CO}_{2}$ desorption earlier (annexe?). Acetone formation from acetate heat treatment is described as carboxylic acid ketonization catalyzed by metal oxides reported by several authors [28]. Acetic acid still formed with use of $\mathrm{ZnSe}$ which is explained by remained amount of $\mathrm{H}_{2} \mathrm{O}$ after dehydration step finished at $170^{\circ} \mathrm{C}$ as proved by A. Musumeci and co. [10]. Moreover, desorbed products analyzation by TPD with corrected $\mathrm{m} / \mathrm{e}$ of $\mathrm{Ni}$ acetate heat decomposition under $\mathrm{He}$ was performed by J.C. De Jesus et al. [8] and they confirm $\mathrm{H}_{2} \mathrm{O}$ desorption at $162^{\circ} \mathrm{C}$ than at $373^{\circ} \mathrm{C}$ with formation of acetic acid and acetone. $\mathrm{KBr}$ use leads to acetic acid selectivity so. 
Transition $7 \rightarrow 8$ illustrates copper methyl formation $\left(\mathrm{CuCH}_{3}\right)$ and adsorbed acetic acid after nucleophilic substitution by $\mathrm{H}_{2} \mathrm{O}$. Concerning adsorbed acetic acid, DRIFT spectra shows (Figure 9(b)) that its band got intensified from $200^{\circ} \mathrm{C}$ to $400^{\circ} \mathrm{C}$ before its decrease within temperature rise under Ar. Simultaneously, acetic acid (as free molecule) is quantified in gas phase by GC-MS from $350^{\circ} \mathrm{C}$ to $500^{\circ} \mathrm{C}$ than falls by the end of decomposition reaction (Scheme $1,8 \rightarrow$ 9). Cho and co. [21] made infrared characterization of $\mathrm{Cu}-\mathrm{CH}_{3}$ and listed 4 main bands at $1612\left(\mathrm{Cu}-\mathrm{H}\right.$ stretching in $\left.\mathrm{CH}_{3}-\mathrm{CuH}^{-}\right), 1203\left(\mathrm{CH}_{3}\right.$ deform in $\left.\mathrm{CH}_{3}-\mathrm{Cu}\right)$, $1012\left(\mathrm{CH}_{3}\right.$ deform in $\left.\mathrm{CH}_{3}-\mathrm{CuH}^{-}\right)$and $648 \mathrm{~cm}^{-1}$. Corresponding bands at 1611, 1198, 1011 and $655 \mathrm{~cm}^{-1}$ were identified on DRIFT spectra (Figure 5(b) and Figure 6(b)) and appeared between 315 and $367^{\circ} \mathrm{C}$ under Ar. The latest bands are not identified under air (except for band at $655 \mathrm{~cm}^{-1}$ which is a large band under air). With increase of heat temperature, $\mathrm{Cu}-\mathrm{CH}_{3}$ on $\mathrm{Cu}_{2} \mathrm{O}$ bond decomposition could lead to $\mathrm{Cu}_{2} \mathrm{O}$, coke and $\mathrm{H}_{2}$ or $\alpha \mathrm{CHx}$ in general $(8 \rightarrow 9$, Scheme 1$)$. At the last step $9 \rightarrow 10$, copper oxide is converted to $\mathrm{Cu}$ with emission of $\mathrm{CO}_{2}$ (re-increase of $\mathrm{CO}_{2}$ level at $500^{\circ} \mathrm{C}$ approximately in Figure 7 (b)).

Last steps of mechanism reaction are resumed by the following reactions equations system (3), (4) and (5) under air and Ar:

$$
\begin{array}{rr}
(\mathrm{CuO})_{2}\left(1-\mathrm{CO}\left(\mathrm{CH}_{3}\right) \mathrm{CH}_{2}\right)_{2} \rightarrow 2 \mathrm{CuO}+6 \mathrm{CO}_{2}+5 \mathrm{H}_{2} \mathrm{O} & 370^{\circ} \mathrm{C}-600^{\circ} \mathrm{C} \text { under air } \\
(\mathrm{CuO})_{2}\left(1-\mathrm{CO}\left(\mathrm{CH}_{3}\right) \mathrm{CH}_{2}\right)_{2} \rightarrow 2 \mathrm{CH}_{3} \mathrm{COOH}+2 \mathrm{Cu}_{2} \mathrm{O}+2 \mathrm{C}+3 \mathrm{H}_{2} \quad 300^{\circ} \mathrm{C}-400^{\circ} \mathrm{C} \text { under Ar } \\
2 \mathrm{CH}_{3} \mathrm{COOH}+2 \mathrm{Cu}_{2} \mathrm{O}+2 \mathrm{C}+3 \mathrm{H}_{2} \rightarrow 2 \mathrm{Cu}+\frac{1}{2} \mathrm{CO}_{2} \quad 400^{\circ} \mathrm{C}-600^{\circ} \mathrm{C} \text { under Ar }
\end{array}
$$

\section{Conclusion}

The present work deals with thermal decomposition of copper acetate monohydrate under air and Ar. A complete analysis of the evolution of infrared spectra matched with crystalline phase transition data allows to underline detailed steps for reaction mechanism. In-line $\mu \mathrm{GC}$-MS results about chronologic desorption of major gaseous products $\left(\mathrm{H}_{2} \mathrm{O}, \mathrm{CO}_{2}\right.$ and $\left.\mathrm{CH}_{3} \mathrm{COOH}\right)$ correlate favorably with DRIFT spectra observations and provide accurate information about intermediates structure of copper acetate during heat treatment. While TGA gives broad conclusion about two steps reaction (dehydration and decarboxylation), in line approach (in situ X-ray and in situ DRIFT coupled to $\mu \mathrm{GC}$-MS) was used to assess $\mathrm{H}_{2} \mathrm{O}$ influence on reaction mechanism under Ar. In fact, $\mathrm{H}_{2} \mathrm{O}$ desorption is incomplete during dehydration step as defined by TGA and residual moieties are essential to conclude $\mathrm{CH}_{3} \mathrm{COOH}$ acetic acid formation, main gas product under Ar. The present in line approach is proposed as an example of a new robust and forward-looking analysis to highlight crucial information about reaction selectivity, conversion and product structure. This tool could be performed also to predict mechanism path way according to reaction media for a large numbre of products and precursors. 


\section{Conflicts of Interest}

The authors declare no conflicts of interest regarding the publication of this paper.

\section{References}

[1] Scalbert, J., Clemencon, I., Legens, C., Diehl, F., Decottignies, D. and Maury, S. (2015) Development of an Innovative XRD-DRIFTS Prototype Allowing Operando Characterizations during Fischer-Tropsch Synthesis over Cobalt-Based Catalysts under Representative Conditions. Oil \& Gas Science and Technology, 70, 419-428. https://doi.org/10.2516/ogst/2014031

[2] Price, G.A., Mallik, D. and Organ, M.G. (2017) Process Analytical Tools for Flow Analysis: A Perspective. Journal of Flow Chemistry, 7, 82. https://doi.org/10.1556/1846.2017.00032

[3] Lin, D.C.K. and Westmore, J.B. (1973) Mass Spectral Studies of Binuclear Metal Complexes: Copper(I) Carboxylates. Canadian Journal of Chemistry, 51, 2999-3005. https://doi.org/10.1139/v73-446

[4] Mansour, S.A.A., Hussein, G.A.M. and Zaki, M.I. (1990) Decomposition of $\mathrm{Cd}\left(\mathrm{CH}_{3} \mathrm{COO}\right)_{2} \cdot 2 \mathrm{H}_{2} \mathrm{O}$ and Creation of Reactive Solid Surfaces-A Spectrothermal Investigation. Reactivity of Solids, 8, 197-208. https://doi.org/10.1016/0168-7336(90)80020-K

[5] Mansour, S.A.A. (1996) Thermoanalytical Investigations of the Decomposition Course of Copper Oxysalts. Journal of Thermal Analysis, 46, 263-274.

https://doi.org/10.1007/BF01979966

[6] Brown, M.E., Dollimore, D. and Galwey, A.K. (1980) Reactions in the Solid State. In: Bamford, C.H. and Tipper, C.F.H., Eds., Comprehensive Chemical Kinetics, Elsevier, Amsterdam, 134-135.

[7] Trimm, D.L. (1980) Design of Industrial Catalysts. In: Churchill, S.W., Ed., Chemical Engineering Monographs, Elsevier, Amsterdam, 3-36.

[8] Jesus, J.C.D., Gonzalez, I., Quevedo, A. and Puerta, T. (2005) Thermal Decomposition of Nickel Acetate Tetrahydrate: An Integrated Study by TGA, QMS and XPS Techniques. Journal of Molecular Catalysis A: Chemical, 228, 283-291. https://doi.org/10.1016/j.molcata.2004.09.065

[9] Ren, G., Hu, D., Cheng, E.W.C., Vargas-Reus, M.A., Reip, P. and Allaker, R.P. (2009) Characterisation of Copper Oxide Nanoparticles for Antimicrobial Applications. International Journal of Antimicrobial Agents, 33, 587-590. https://doi.org/10.1016/j.ijantimicag.2008.12.004

[10] Musumeci, A. and Frost, R.L. (2007) A Spectroscopic and Thermoanalytical Study of the Mineral Hoganite. Spectrochimica Acta Part A: Molecular and Biomolecular Spectroscopy, 67, 48-57. https://doi.org/10.1016/j.saa.2006.05.037

[11] Buti, D., Rosi, F., Brunetti, B.G. and Miliani, C. (2013) In-Situ Identification of Copper-Based Green Pigments on Paintings and Manuscripts by Reflection FTIR. Analytical and Bioanalytical Chemistry, 405, 2699-2711. https://doi.org/10.1007/s00216-013-6707-6

[12] Lin, Z., Han, D. and Li, S. (2012) Study on Thermal Decomposition of Copper(II) Acetate Monohydrate in Air. Journal of Thermal Analysis and Calorimetry, 107, 471-475. https://doi.org/10.1007/s10973-011-1454-4

[13] Afzal, M., Butt, P.K. and Ahmad, H. (1991) Kinetics of Thermal Decomposition of Metal Acetates. Journal of Thermal Analysis, 37, 1015-1023.

https://doi.org/10.1007/BF01932799 
[14] Mathey, Y., Greig, D.R. and Shriver, D.F. (1982) Variable-Temperature Raman and Infrared Spectra of the Copper Acetate Dimer $\mathrm{Cu}_{2}\left(\mathrm{O}_{2} \mathrm{CCH}_{3}\right)_{4}\left(\mathrm{H}_{2} \mathrm{O}\right)_{2}$ and Its Derivatives. Inorganic Chemistry, 21, 3409-3413. https://doi.org/10.1021/ic00139a028

[15] Kaftan, A., Kusche, M., Laurin, M., Wasserscheid, P. and Libuda, J. (2017) $\mathrm{KOH}$-Promoted $\mathrm{Pt} / \mathrm{Al}_{2} \mathrm{O}_{3}$ Catalysts for Water Gas Shift and Methanol Steam Reforming: An Operando DRIFTS-MS Study. Applied Catalysis B: Environmental, 201, 169-181. https://doi.org/10.1016/j.apcatb.2016.08.016

[16] Wanjun, T. and Donghua, C. (2007) Mechanism of Thermal Decomposition of Cobalt Acetate Tetrahydrate. Chemical Papers, 61, 329-332.

[17] Zhang, K.L., Hong, J.H., Cao, G.H., Zhan, D., Tao, Y.T. and Cong, C.J. (2005) The Kinetics of Thermal Dehydration of Copper(II) Acetate Monohydrate in Air. Thermochimica Acta, 437, 145-149. https://doi.org/10.1016/j.tca.2005.06.038

[18] Hudson, R.L., Gerakines, P.A. and Ferrante, R.F. (2018) IR Spectra and Properties of Solid Acetone, an Interstellar and Cometary Molecule. Spectrochimica Acta Part A: Molecular and Biomolecular Spectroscopy, 193, 33-39. https://doi.org/10.1016/j.saa.2017.11.055

[19] Smith, B.C. (2017) The Carbonyl Group, Part I: Introduction. Spectroscopy, 32, 31-36.

[20] DeCoste, J.B., Peterson, G.W., Schindler, B.J., Killops, K.L., Browe, M.A. and Mahle, J.J. (2013) The Effect of Water Adsorption on the Structure of the Carboxylate Containing Metal-Organic Frameworks Cu-BTC, Mg-MOF-74, and UiO-66. Journal of Materials Chemistry A, 1, 11922-11932. https://doi.org/10.1039/c3ta12497e

[21] Cho, H.G. and Andrews, L. (2011) Infrared Spectra of $\mathrm{CH}_{3}-\mathrm{MH}, \mathrm{CH}_{3}-\mathrm{M}$, and $\mathrm{CH}_{3}-\mathrm{MH}$-Prepared via Methane Activation by Laser-Ablated $\mathrm{Au}, \mathrm{Ag}$, and $\mathrm{Cu}$ Atoms. Dalton Transactions, 40, 11115-11124. https://doi.org/10.1039/c0dt01827a

[22] Dudev, T. and Lim, C. (2004) Monodentate versus Bidentate Carboxylate Binding in Magnesium and Calcium Proteins: What Are the Basic Principles? The Journal of Physical Chemistry B, 108, 4546-4557. https://doi.org/10.1021/jp0310347

[23] Mekhemer, G.A.H., Halawy, S.A., Mohamed, M.A. and Zaki, M.I. (2005) Ketonization of Acetic Acid Vapour over Polycrystalline Magnesia: In Situ Fourier Transform Infrared Spectroscopy and Kinetic Studies. Journal of Catalysis, 230, 109-122.

https://doi.org/10.1016/j.jcat.2004.09.030

[24] Campbell, G.C., Reibenspies, J.H. and Haw, J.F. (1991) Solid-State NMR Studies of Magneto-Structural Correlations in Anhydrous Copper(II) Carboxylates. Inorganic Chemistry, 30, 171-176. https://doi.org/10.1021/ic00002a006

[25] Sharrock, P. and Melnik, M. (1985) Copper(II) Acetates: From Dimer to Monomer. Canadian Journal of Chemistry, 63, 52-56. https://doi.org/10.1139/v85-009

[26] Bellini, J.V., Machado, R., Morelli, M.R. and Kiminami, R.H.G.A. (2002) Thermal, Structural and Morphological Characterisation of Freeze-Dried Copper(II) Acetate Monohydrate and Its Solid Decomposition Products. Materials Research, 5, 453. https://doi.org/10.1590/S1516-14392002000400010

[27] Costa, G., Camus, A. and Marsich, N. (1965) Copper Methoxides Formed by Thermal Decomposition of Copper Methyl in Methanol. Journal of Inorganic and Nuclear Chemistry, 27, 281-285. https://doi.org/10.1016/0022-1902(65)80339-6

[28] Wang, S. and Iglesia, E. (2017) Experimental and Theoretical Assessment of the Mechanism and Site Requirements for Ketonization of Carboxylic Acids on Oxides. Journal of Catalysis, 345, 183-206. https://doi.org/10.1016/j.jcat.2016.11.006 
Annex, Scheme 1: $\mathrm{Cu}(\mathrm{Ac})_{2} \cdot \mathrm{H}_{2} \mathrm{O}$ Reaction Mechanism of Thermal Decomposition under Air and Ar

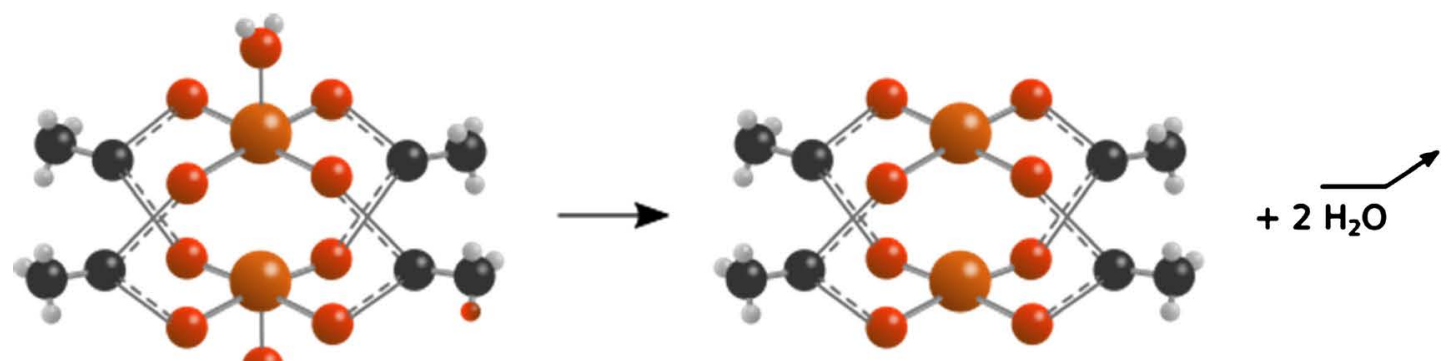

(1)

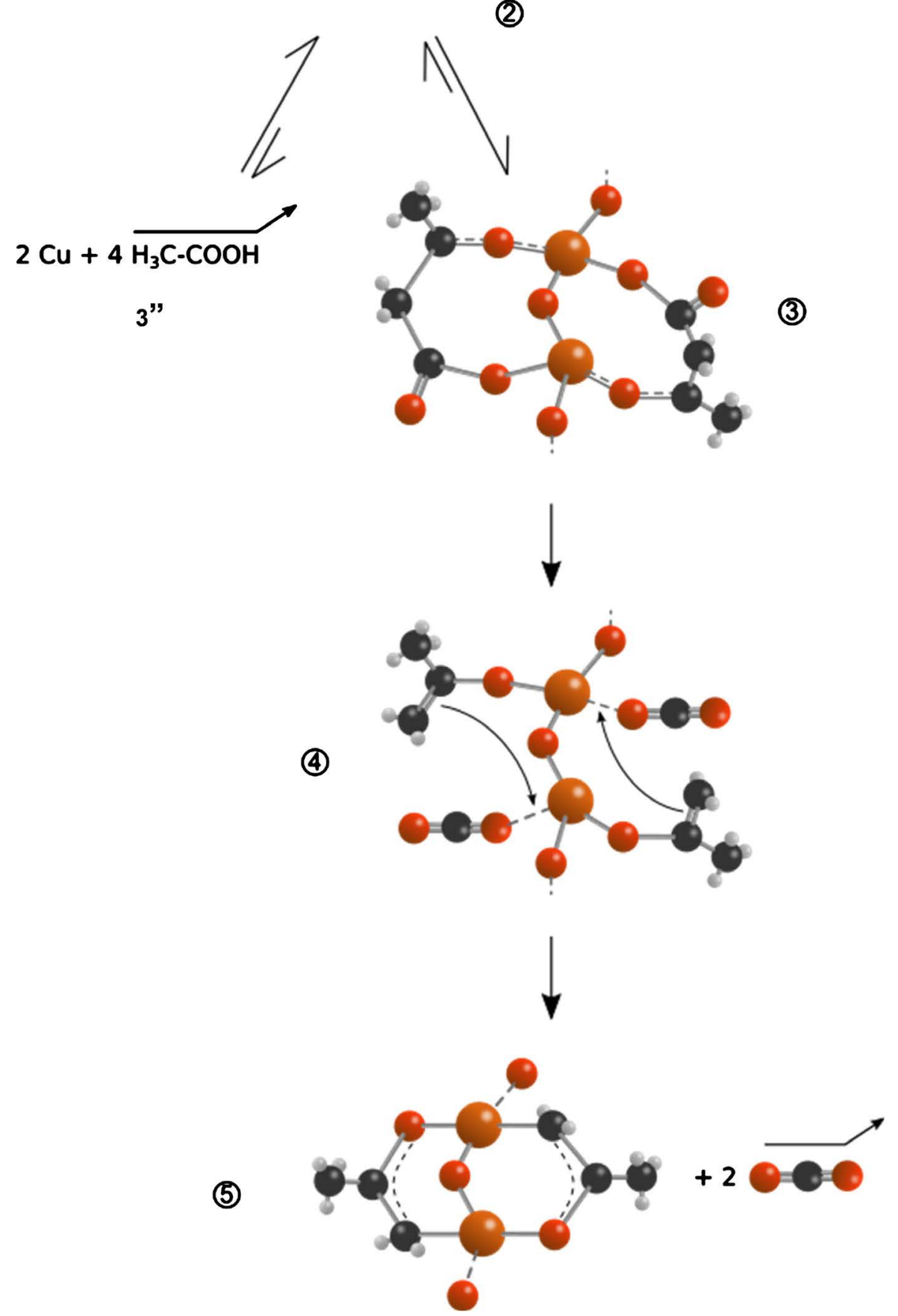




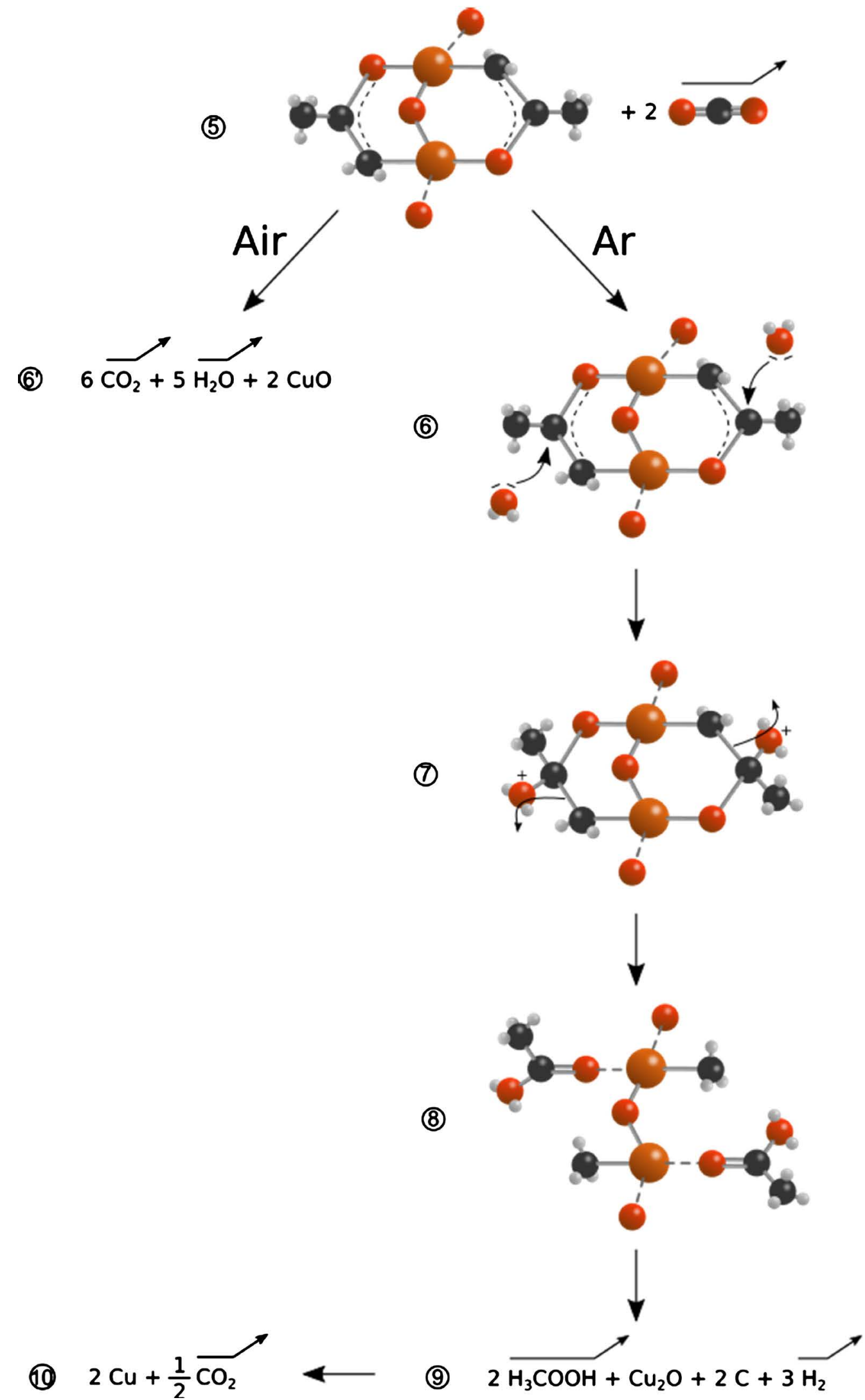

